\title{
Child and adolescent violence: oral story of women who attempted suicide
}

\author{
Violência na infância e adolescência: história oral de mulheres que tentaram suicídio \\ Violencia en la infancia y adolescencia: historia oral de mujeres que intentaron suicidio
}

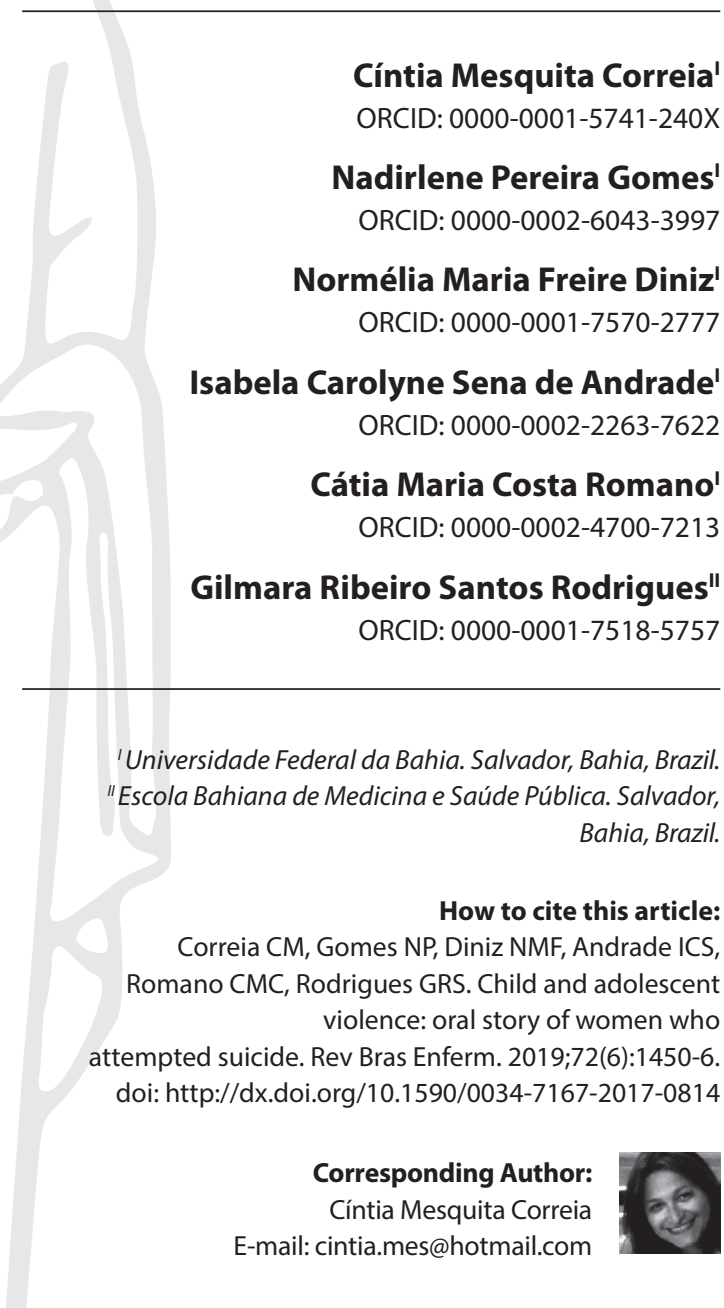

Submission: 12-05-2017 Approval: 03-01-2019

\begin{abstract}
Objective: To unveil expressions of intrafamily violence experienced in childhood and/or adolescence by women who attempted suicide. Method: This is a study with a qualitative approach based on Oral Story. Participants were ten women with a history of suicide attempt, who experienced intrafamily violence in childhood and/or adolescence. The research was carried out at the Center for the Study and Prevention of Suicide, linked to a Toxicological Information Center in the city of Salvador, Bahia, Brazil. Results: From the orality of women, the study allowed the emergence of the following representative categories of intrafamily abuse experienced in childhood and/or adolescence: psychological violence, rejection, neglect, physical violence and sexual violence. Final considerations: The study alerts to intrafamily violence as an aggravation related to suicidal behavior, offering elements that help in the identification of their expressions, which will raise awareness to suicidal behavior and consequently suicide prevention.

Descriptors: Child Abuse; Adolescent; Domestic Violence; Violence Against Women; Suicide, Attempted.
\end{abstract}

\section{RESUMO}

Objetivo: Desvelar as expressões da violência intrafamiliar vivenciadas na infância e/ou adolescência por mulheres que tentaram suicídio. Método: Trata-se de um estudo com abordagem qualitativa, fundamentada na História Oral. Participaram dez mulheres com história de tentativa de suicídio, que experienciaram violência intrafamiliar na infância e/ou adolescência. A pesquisa foi realizada no Núcleo de Estudo e Prevenção do Suicídio, vinculado a um Centro de Informação Toxicológica na cidade de Salvador, Bahia, Brasil. Resultados: A partir da oralidade das mulheres, o estudo permitiu emergir as seguintes categorias representativas da expressão de abuso intrafamiliar vivenciada na infância e/ou adolescência: violência psicológica (rejeição, negligência), violência física e violência sexual. Considerações finais: $O$ estudo alerta para a violência intrafamiliar enquanto agravo relacionado ao comportamento suicida, oferecendo elementos que auxiliam na identificação de suas expressões, o que possibilitará atenção para o comportamento suicida e consequentemente prevenção do suicídio.

Descritores: Maus-Tratos Infantis; Adolescente; Violência Doméstica; Violência Contra a Mulher; Tentativa de Suicídio.

\section{RESUMEN}

Objetivo: Desvelar las expresiones de la violencia intrafamiliar vivenciadas en la infancia y/o adolescencia por mujeres que intentaron suicidio. Método: Se trata de un estudio con enfoque cualitativo, fundamentado en la Historia Oral. Participaron diez mujeres con historia de intento de suicidio, que experimentaron violencia intrafamiliar en la infancia y/o adolescencia. La investigación fue realizada en el Núcleo de Estudo e Prevenção do Suicídio (Núcleo de Estudio y Prevención del Suicidio), vinculado a un Centro de Información Toxicológica en la ciudad de Salvador, Bahía, Brasil. Resultados: A partir de la oralidad de las mujeres, el estudio permitió emerger las siguientes categorías representativas de la expresión de abuso intrafamiliar vivenciada en la niñez y/o adolescencia: violencia psicológica (rechazo y negligencia), violencia física y violencia sexual. Consideraciones finales: El estudio alerta sobre la violencia intrafamiliar como agravio relacionado al comportamiento suicida, ofreciendo elementos que auxilian en la identificación de sus expresiones, lo que posibilitará atención para el comportamiento suicida y consecuentemente la prevención del suicidio.

Descriptores: Maltrato a los Niños; Adolescentes; Violencia Doméstica; Violencia Contra la Mujer; Intento de Suicidio. 


\section{INTRODUCTION}

Intrafamily violence experienced in childhood and/or adolescence is a worldwide problem with serious repercussions on the health of victims. Perpetrated by people who should safeguard the protection of children and adolescents, this phenomenon significantly affects the lives of those who experience it, and can even lead to suicide.

As an offense of public interest, intrafamily violence is a frequent occurrence in the daily lives of many children and adolescents. A study of 870 children under 13 municipal schools in the city of Araçatuba, São Paulo State Brazil, revealed that 272 were victims of violence, and parents and/or guardians were identified as the main abusers in $58.4 \%$ of the cases ${ }^{(1)}$. Data released by the Observatório da Criança e do Adolescente (National Observatory on Childhood and Adolescence), according to information from the Ministry of Justice and Citizenship, showed a total of 74,395 reports of violence against children and adolescents made by dial 100 only in the first half of $2016^{(2)}$.

An international research conducted in Haiti, Kenya and Cambodia, with a population of 4,170 people, showed that about $43.5 \%$ suffered violence when children and/or adolescents ${ }^{(3)}$. A North American study on child and adolescent sexual abuse carried out with 2,508 adults aged 21 years reveals, through retrospective self-reports, experiences of violence from 5 to 16 years of age in 943 young people in the sample ${ }^{(4)}$.

In the context of intrafamily violence, the veiled nature of this grievance cannot be disregarded ${ }^{(5)}$, especially because of the difficulty of children/adolescent to reveal it; the fear of the family in denouncing it, since perpetrators are commonly people of family circle; and professional unpreparedness for the identification and notification of the same ${ }^{(6)}$. This situation ends up making it even more vulnerable and for much longer, children and adolescents in the context of violence within their own homes.

However, a life history permeated by experiences of violence in childhood and/or adolescence can have negative repercussions on the development process of individuals. This commitment can be evidenced from the narratives of adolescents victims of intrafamily violence who presented disinterest, dispersion and lack of attention in the classroom, learning difficulties and low income ${ }^{(7)}$. Experiencing it can also affect the physical and mental health of minors, making them vulnerable to problems such as social isolation, alcoholism, anxiety disorders, post-traumatic stress disorder, depression and suicidal behavior ${ }^{(3,8)}$.

Repercussions of all types of abuse, especially when experienced in childhood and/or adolescence, seriously compromise emotional and cognitive development, with associations between the emergence of somatic diseases, such as cardiovascular and psychosomatic disorders, such as bipolar disorder and suicidal behavior ${ }^{(9)}$. In Japan, which ranks sixth in the world ranking of suicide deaths, a multicenter study of 17,530 adolescents from public schools has found the association between family violence and suicidal behavior in $31.9 \%$ of the participants ${ }^{(10)}$.

Interface between experiencing intrafamily violence in childhood/ adolescence period and thoughts of death, whose scientific evidence has been discussed nationally and internationally, is thus perceived. Considering the magnitude and complexity of the phenomenon, it is essential to identify early intrafamilial violence experienced by children and adolescents, especially in the prevention of serious damage during life, such as suicidal behavior, based on the assumption that the understanding about forms of violence will favor the recognition of the aggravation by health professionals, especially those who work within the scope of Family Health Strategy (FHS).

\section{OBJECTIVE}

To unveil expressions of intrafamily violence experienced in childhood and/or adolescence by women who attempted suicide.

\section{METHOD}

\section{Ethical aspects}

The research project complied with Resolution 466/2012 of the National Health Council, which deals with ethical aspects of research involving human beings. It was submitted to the Ethics in Research Committee, with approval under Opinion 50/2010.

\section{Methodological framework}

It is a research based on Oral Story, a method that provides great contribution to the rescue of memory and lived experiences ${ }^{(11)}$. The Thematic Oral Story modality was used as methodological framework, because it allows to direct the subjective views and understandings, as well as the diverse ways of seeing and feeling the adversities experienced about a certain object ${ }^{(12)}$.

\section{Type of study}

This is an exploratory and descriptive study, with qualitative approach.

\section{Methodological procedures}

Interviews were conducted based on the assumptions of the Thematic Oral Story, focusing on the object of this study: expressions of intrafamily violence experienced in childhood and/or adolescence by women who attempted suicide.

\section{Study setting}

The study was carried out at the Brazilian Center for the Study and Prevention of Suicide (NEPS), linked to a Toxicological Information Center (CIAVE), a state referral service in the orientation to cases of intoxication, including accidents by venomous animals and attempts to suicide by poisoning in the city of Salvador. As an outpatient service, the NEPS is a reference in the follow-up of persons at risk of suicide. This service setting occurred by observing the unit's routine in the waiting room, in moments that preceded individual consultations, besides the participation in group activities with users. This process enabled the strengthening of bonds of trust and respect, favoring the sharing of their life stories.

Considering the importance of subjects having in common memories of testimony of the victim's testimony in an individual and subjective way, according to Oral Story presuppositions, 
collaborators were women with a history of suicide attempt. As inclusion criteria, we considered: being in psychiatric and psychological follow-up at NEPS for at least a year; being at least 18 years and reporingt on intrafamily violence in childhood and/or adolescence. Indication of possible collaborators was favored by the support of the psychology coordination of NEPS. These professionals identified women who experienced intrafamily violence in childhood and/or adolescence, as well as assessed their emotional and psychic conditions to participate in the study.

Thus, those who were considered eligible were invited to collaborate with the study, being previously clarified as to the damages or risks related to participation in the research, faced with the possibility of embarrassment and/or several other feelings when sharing their experiences, through information personal or confidential. In view of this situation, they were provided with immediate psychotherapeutic care by professionals working at NEPS. They were also informed about the right of refusal or withdrawal, at any time of the research, without interference in the follow-up carried out in the service. At the end of explanations about the research, ten women signed the Free and Informed Consent Form.

\section{Coleta e organização dos dados}

Data collection was carried out at NEPS' facilities between June and December 2010 through the in-depth interview. From the narratives of people who witnessed or witnessed events or conjunctures, this technique makes possible the search for detailed perceptions from individual points of view. In this way, it favors a better understanding about the phenomena, as well as their relationships and interactions with the people involved in these contexts ${ }^{(13)}$. Thus, it is possible to reveal experiences of intrafamily violence in childhood and/or adolescence by women who attempted suicide.

Statements were recorded and transcribed in full and all this material filed for five years, and then cremated. Codenames were assigned in order to preserve the identity of members.

\section{Data analysis}

With the transcribed material, data were coded based on Bardin's Thematic Analysis, which aims to obtain through systematic procedures and objective description messages content, indicators that allow the interference of knowledge regarding conditions of production/reception of these messages. Operationalization of the thematic analysis described by Bardin followed three chronological poles, namely: exhaustive reading of the raw material (pre-analysis); exploitation of the material with consequent codification of data and choice of registration units for analysis (categorization); and treatment of results by interpretation and inference ${ }^{(14)}$.

Following the data organization stages, the following categories emerged representing expressions of intrafamily abuse experienced in childhood and/or adolescence: psychological violence, rejection, neglect, physical violence and sexual violence.

\section{RESULTS}

The study's collaborators are women who attempted suicide between one and four times, all due to poisonings with medication or rodenticides. Between 27 and 57 years of age, the majority is black, has low schooling and depends totally or partially on their partners.

As to the experience of intrafamily violence in childhood and/ or adolescence, oral story of women reveals that it was expressed in psychological, sexual and physical forms, as the categories illustrate, namely:

\section{Psychological violence}

From the orality of women with a history of suicide attempt, the study reveals a childhood and/or adolescence permeated by psychological violence within the family context. This form of expression manifested itself through rejection and neglect, as the categories indicate:

\section{Rejection}

The women interviewed reported that in childhood and/or adolescence they perceived themselves humiliated and depreciated by their parents. It alerts us to the interface between suicidal behavior and the feeling of contempt, especially for being aware of rejection from the gestation.

I've always felt rejection from my parents. [...] I felt so bad that I thought about killing myself. [...] my mother did not even care and still said to me to kill myself. (Acacia)

My mother rejected me from the wound and did not want to breastfeed because she said that I looked like a frog. [...] she said that I was found in the trash, that I only weaken and that I would be nobody in life. When I tried suicide, and I did not die, I thought that even for that I was useless. (Camellia)

\section{Neglect}

Women with suicidal behavior also express the memory of a childhood permeated by the absence of affectivity and violation of the right to leisure, with adult obligations attributed to them.

My mother could not be lovable with me.. [...] there was no affection and hugs between us. If there was no longer synchrony between me and my mother, it worsened after the depression and the suicide attempt. (Azalea)

Since when I was eleven I had no right to any kind of leisure. I have always had many duties. [...] I lived to raise my brothers. I was the one who took care of everything at home. (Fleur-de-lis)

\section{Sexual violence}

Sexual violence was revealed in the orality of reports through incestuous relationships practiced by people who occupy social positions of trust and/or power in family ties. Disbelief on the part of relatives is aggravated when the child reveals sexual violence, situation that occurs mainly in front of the abuser's deny.

I suffered sexual abuse at around age twelve or thirteen. My body was not yet formed. [...] my cousin used to go to my bed. He did this 
a few times. [...] I told Grandma, but he [cousin] denied everything. [...] I felt frustration and impotence. (Rosemary)

I was seven or eight when I was raped by my stepfather; and eleven when I was raped by my grandfather. [...] I told them, but no one believed! I thought no one would want me because of it. I wanted to disappear! (Widow Flower)

\section{Physical violence}

The speeches refer to the history of physical aggression perpetrated by parents, being remembered even experiences of beatings.

I was just a child when my mother physically assaulted me and I did not know what to do! That affected me a lot. (Orchid)

In childhood and adolescence, I suffered a lot of beating by my father. [...] I perceived a relationship between violence and my health. (Iris)

\section{DISCUSSION}

The collaborators of the study are women with history of violence and suicide attempts, which is justified because they are the population segment that most experiences violence. Violence is often silenced in the private sphere and at the heart of family relationships, with repercussions for physical and mental illness, such as suicidal behavior.

Through oral story of women who attempted suicide, the study reveals that they experienced a childhood and/or adolescence affected by intrafamily violence. The relationship between violence, depressive signs and suicidal ideation was also noted in a study of 588 university students, of which $10 \%$ of those with a history of domestic violence reported depressive symptoms associated with suicidal behavior in the last two weeks preceding the study ${ }^{(15)}$. Similarly, a survey of more than 1,000 adults in treatment for depression in 17 locations across the United States, the Netherlands, Australia, New Zealand and South Africa revealed that more than half reported experiencing a childhood affected by intrafamily violence ${ }^{(16)}$.

Among the forms of expression of violence emerged through the victim's memories, the interviewees revealed the feeling of rejection and depreciation by their parents. A study focused on orality of schoolchildren also revealed a childhood and adolescence affected by privations of affection and rejection ${ }^{(17)}$. It draws attention to the perception of experiencing this kind of violence from even intrauterine life. Faced with such a reality, it should be pointed out that fragile emotional bonds between mothers and babies can have different repercussions for the development of the fetus and, later, the child. As an example, the research with primiparous women in the United Kingdom confirms association between maternal rejection from the antenatal period and symptoms of mental and behavioral disorders in the development of children and adolescents, such as depression and personality disorders ${ }^{(18)}$

Another situation may be exemplified in a North American study using data from the National Survey of Family Growth, which analyzed 4,297 women for desired or unwanted pregnancies, as well as their interface with maternal behavior for antenatal care and breastfeeding. Results showed that women whose children came from unwanted pregnancies performed antenatal care late and exclusive breastfeeding for less than six months ${ }^{(19)}$. It is worth mentioning that the refusal of breastfeeding is consonant in the orality of one of the women interviews, perceived from the following representative memory: "she did not want to breastfeed because she said that I looked like a frog".

Still with regard to rejection, it is still necessary to consider that although in some situations a priori there is no acceptance of pregnancy, this can change over time. A study shows that in situations of unplanned pregnancy, rejection is common, including attempts at abortion. However, with the maintenance of gestation, the woman can re-signify her relationship with the fetus, starting to desire it. A survey of 150 women of Caucasian, African American, Latino and Asian origin ratifies an improved bond in the affective relationship of mothers and children to unwanted pregnancies up to six months after birth. Over time, mothers began to interact in games and games with their children, became more present in the daily care of the baby, and showed more affection and affection for the children ${ }^{(20)}$. Unlike the interviewees in question, the study signals the permanence of memories and feelings of rejection at all stages of life, even when adults. This is due to the constant presence of the past, as well as significant, representative and selected fragments of the experience of violence perpetrated during life ${ }^{(21)}$. Thus, women rescue their traumatic memories, increasing their chances of remembrance of their pain.

The study also revealed the rejection expressed through offenses and humiliations within the intrafamily every day. Women who participated in the study are not able to prevent certain memories from coming to life nor to control how they will come out of the realm of the intimate, private, and gain their own form in the public. For this reason, intimate relationship between violence and mental suffering has been observed in several studies, unfolding in self-destructive and even suicidal behaviors. A research that shows the testimony of offenses and humiliations experienced by children and adolescents in the intrafamilial context alerts to the interface between this experience and psychological and/or psychic illness, evidenced by feelings of sadness, social isolation, self-mutilation behaviors and suicidal thoughts that may adulthood ${ }^{(17)}$.

It is aggravated by the non-crediting of the suffering of the individual, signaled by the words "my mother did not even care and still said to me to kill myself", suggesting the lack of understanding of the process of mental illness, a situation that may increase the risk for attempts of suicide and/or its consummation. It is important to emphasize the significance of maternal and paternal figures for the individual in formation in the process of interaction with the other and with the social environment. In childhood, formation of memories is an essential element of the construction of identity and perception of self and others ${ }^{(22)}$. In this sense, when valuing such figures, children and adolescents tend to introject the victim, so that they truly believe in what these people say. This is the case with Camellia, who internalizes the mother's sense of uselessness and failure, even when she is not successful for suicide. 
Still in the midst of rejection, women lament for a needy and uncaring childhood and adolescence. Characterized as affective neglect, lack of affectivity is also considered as a form of violation of rights of the child and the adolescent. It is the duty of the family and of society in general to ensure, in addition to food, health and education, the realization of any and all rights related to life, dignity, respect and freedom, regardless of living spaces such as the provisions of the Child and of Adolescents Statue (ECA - Estatuto da Criança e do Adolescente), by Law 8,069, of July 13, 1990(23).

This document also points out the deprivation of leisure, especially from the imputation of responsibilities inherent to adults such as the creation of other individuals and domestic care, a condition experienced by the women under study. It is worth mentioning that situations related to the lack of leisure, access to culture, sport and professionalization are still characterized as deprivation of rights, with serious repercussions for adult life. This is evidenced by a European study with 210 women and 220 men who presented a low tolerance to deal with emotions and frustrations, as well as a high occurrence of anxiety and depression as a reflection of adversities experienced in childhood ${ }^{(24)}$.

It is worth noting that at this juncture, where children take adult responsibilities, punishment as an educational ideal is common when the tasks assigned to them are not fulfilled or performed as expected. The use of punitive methods for child and adolescent education is common in the culture of several countries, as in the United States, where research has shown that $76 \%$ of men and $65 \%$ of women agree that a child sometimes needs a "Good spanking", generalizing the use of corporal punishment as a method of raising children ${ }^{(25)}$.

In Brazil, due to the existence of socio-cultural aspects related to the use of corporal punishment and/or cruel or degrading treatment, as also evidenced in our study, the country adopted on December 20, 1996 the "Menino Bernardo Law" (LeiMenino Bernardo), popularly known as the "Spanking" Law. It amends ECA's Law 8,069 to establish the right of the child and adolescent to be educated and cared for without any disciplinary or punitive actions, such as the use of physical force, resulting in physical suffering or injury ${ }^{(26)}$.

Although there is a didactic systematization regarding expressions of violence, it is necessary to understand that not only physical violence implies physical damage and pain, since sexual violence also causes repercussions of a physical nature. For example, fissures and lacerations arising from vaginal penetration can be mentioned, especially when body structures are still in the formation and maturation phase, as in the case of Rosemary.

In addition to physical damage, studies indicate other health problems for children suffering from this type of violence, such as low school performance, low or no social adjustment, difficulties in the sexual sphere, low self-esteem, development of psychosomatic diseases, chronic fatigue syndrome, personality and post-traumatic stress disorders, anxiety, panic, self-injurious and/or aggressive and suicidal behavior ${ }^{(27-28)}$.

Some of these signs emerge in the interviewees' testimony, such as the belief that they will not be able to establish affective bonds, especially in the sexual area. Corroborating that this type of violence can negatively affect the image and self-esteem of women for many years, contributing to the difficulty of finding partners or even maintaining lasting affective commitments, other problems associated with aggravation are sexual dissatisfaction, loss of pleasure and pain ${ }^{(29-30)}$.

It is also noted that it is impossible for the child to break with the cycle of sexual violence. This is primarily because abusers are individuals in the family, such as stepfathers, grandparents and cousins, as in the case of this study, or even people from the neighborhood and house of relatives. Because these are the main offenders, considered reliable within the family, it is not uncommon to discredit child's prosecution $^{(31)}$, a situation recalled by one of the interviewees.

It is also considered the decision of those responsible not to denounce a family entity since abuser's revelation can de-structure affective, social and family relations and cause imbalance, separation and disintegration of the family nucleus ${ }^{(27)}$. However, even when the family decides to represent the case to the authorities, many situations of abuse remain unpunished, according to a study by Nigeria with two cases of sexual abuse carried out by a neighbor and by a family member close to the victim, in which the men escaped from any punishment after a complaint from the victims' parents ${ }^{(32)}$.

This reality makes children and adolescents vulnerable to experiencing years and years of sexual abuse that can perpetuate even in adulthood, acting as a risk factor for suicide attempts. This is because this reality triggers feelings of insecurity and fear on the part of the child/adolescent, as well as changes in the individual's emotional and behavioral state such as: low self-esteem, more aggressive or introverted behaviors and feelings of guilt, shame or even affection and relation to the abuser ${ }^{(33-34)}$.

Regarding sexual abuse, a study in China showed that this type of violence in the first 16 years of life, especially with continuous exposure, was significantly associated with depression and suicide attempts. This association was also verified for physical and emotional abuse, so that among the 14,221 students studied, of the $51 \%$ with a history of intrafamily violence, $26.6 \%$ presented suicidal ideation, plans of death and suicide attempt ${ }^{(35)}$. Thus, the study indicates that, regardless of the way violence is expressed, this aggravation acts as an important risk factor for suicide attempts.

Given expression forms of intrafamilial violence revealed in the study and scientific evidence about its interface with suicidal behavior, it is important to highlight the professional preparation for the early identification of children and adolescents suffering from domestic abuses. Considering the assumptions of bonding and trust with the victim, nurses and doctors who work in the FHS are in a strategic position to recognize early situations of violence, favoring the adoption of intervention actions in order to better target care, foster care and outcome ${ }^{(36-37)}$.

In the scenario of care for children and adolescents, it is up to the partnership between health professionals and educators in order to think about prevention and coping with the phenomenon, such as articulation with families. In the meantime, the School Health Programme (PSE - Programa Saúde na Escola) is inserted, which aims to identify and intervene in social vulnerabilities that may in some way compromise the life of schoolchildren ${ }^{(27,38)}$, such as intrafamily violence.

\section{Study limitations}

Although limited by not establishing a cause-and-effect relationship, the study alerts to intrafamily violence as an aggravation related to the ideas of suicide, attempted suicide and suicide. 


\section{Contributions to the fields of Nursing, Health or Public Policy}

The study offers elements that help health professionals, especially from nursing, to identify expressions of intrafamily violence (physical, psychological and sexual violence) in childhood/adolescence. It provides, therefore, subsidies to enable the perception of the magnitude of intrafamily violence, since this may lead to suicide attempts or suicide in people's lives, especially women.

\section{FINAL CONSIDERATIONS}

Orality of women with a history of suicide attempts reveals a childhood and/or adolescence marked by intrafamily violence, expressed by psychological, sexual and physical abuse. These forms of manifestations of abuse need to be better understood by health professionals in order to favor their early recognition and thus appropriate interventions for the purpose of reducing suicide rates.
Stories of abuse, even as children and adolescents, marked so deeply the lives of those interviewed, who took root in their memories in order to function as possible triggers for the suicide attempt. In reliving this pain, whenever recalled, the woman begins to express in the body all the suffering of violence experienced in the family meal. Thus, suicidal behavior is revealed as an effect of pain somatization experienced in childhood/adolescence.

\section{ACKNOWLEDGMENT}

A special thanks to everyone who contributed to the performance of this study, especially to the women who by talking about their own experiences shared and relived with us precious moments of life; also to the professionals from the Brazilian Center for the Study and Prevention of Suicide, especially Soraya Carvalho and Maíra Cerqueira, for their commitment to the human, no matter how long it takes for the continuity of existence to become light.

\section{REFERENCES}

1. Garbin CAS, Araújo PC, Rovida TAS, Rocha AC, Arcieri RM, Garbin AJI. Violência na população infantil: perfil epidemiológico dos abusos verificados no ambiente escolar. Rev Ciênc Plur [Internet]. 2016 [cited 2017 Jul 20];2(2):41-54. Available from: https://periodicos.ufrn.br/ rcp/article/view/10122

2. Fundação Abrinq. Observatório da Criança e do Adolescente[Internet]. São Paulo: Fundação Abrinq; 2015. [cited 2017 Jul 08]. Available from: https://observatoriocrianca.org.br

3. Sumner SA, Mercy JA, Buluma R, Mwangi MW, Marcelin LH, Kheam T, et al. Childhood Sexual Violence Against Boys: A Study in 3 Countries. Pediatrics. 2016;137(5):e20153386. doi: 10.1542/peds.2015-3386

4. Mills R, Kisely S, Alati R, Strathearn L, Najman J. Self-reported and agency-notified child sexual abuse in a population-based birth cohort. J Psychiatr Res. 2016;74:87-93. doi: 10.1016/j.jpsychires.2015.12.021

5. Roque EMST, Ferriani MGC, Gomes R, Silva LMP, Carlos DM. Justice system and secondary victimization of children and or adolescents victims of sexual violence in the family. Saude Soc. 2014;23(3):801-13. doi: http://dx.doi.org/10.1590/S0104-12902014000300006

6. Rates SMM, Melo EM, Mascarenhas MDM, Malta DC. Violence against children: an analysis of mandatory reporting of violence, Brazil 2011. Ciênc Saúde Colet. 2015;20(3):655-65. doi: http://dx.doi.org/10.1590/1413-81232015203.15242014

7. Magalhães JRF, Gomes NP, Mota RS, Campos LM, Camargo CL, Andrade SR. Intra-family violence: experiences and perceptions of adolescents. Esc Anna Nery. 2017;21(1):e20170003. doi: http://dx.doi.org/10.5935/1414-8145.20170003

8. Moore SE, Scott JG, Ferrari AJ, Mills R, Dunne MP, Erskine HE, et. al. Burden attributable to child maltreatment in Australia. Child Abuse Negl. 2015;48:208-20. doi: 10.1016/j.chiabu.2015.05.006

9. Jaworska-Andryszewska P, Rybakowski J. Negative experiences in childhood and the development and course of bipolar disorder. Psychiatr. Pol. 2016;50(5):989-1000. doi: https://doi.org/10.12740/PP/61159

10. Fujikawa S, Ando S, Shimodera S, Koike S, Usami S, Toriyama R, Kanata S, et al. The association of current violence from adult family members with adolescent bullying involvement and suicidal feelings. PLoS ONE. 2016;11(10):e0163707. doi: https://doi.org/10.1371/ journal.pone.0163707

11. Thompson P. A voz do passado. São Paulo: Paz e Terra; 1992.

12. Albert V. Manual de História Oral. 3a ed. Rio de Janeiro: FGV; 2005.

13. Godoi CK, Mattos PLCL. Entrevista Qualitativa: Instrumento de pesquisa e evento dialógico. Pesquisa qualitativa em estudos organizacionais: paradigmas, estratégias e métodos. 2a ed. São Paulo: Saraiva; 2010.

14. Bardin L. Análise de conteúdo. 70a ed. São Paulo; 2011.

15. Wolford-Clevenger C, Vann NC, Smith PN. The association of partner abuse types and suicidal ideation among men and women college students. Violence Vict. 2016;31(3):471-85. doi: 10.1891/0886-6708.VV-D-14-00083

16. Williams LM, Debattista C, Duchemin AM, Schatzberg AF, Nemeroff CB. Childhood trauma predicts antidepressant response in adults with major depression: data from the randomized international study to predict optimized treatment for depression. Transl Psychiatry. 2016;6(5):e799. doi: 10.1038/tp.2016.61

17. Magalhães JRF, Gomes NP, Campos LM, Camargo CL, Estrela FM, Couto TM. The expression of intrafamily violence: adolescent oral histories. Texto Contexto Enferm. 2017;26(4):e1730016. doi: http://dx.doi.org/10.1590/0104-07072017001730016 
18. Pickles A, Sharp H, Hellier J, Hill J. Prenatal anxiety, maternal stroking in infancy, and symptoms of emotional and behavioral disorders at 3.5 years. Eur Child Adolesc Psychiatry. 2017;26(3):325-34. doi: 10.1007/s00787-016-0886-6

19. Maddow-Zimet I, Lindberg L, Kost K, Lincoln A. Are pregnancy intentions associated with transitions into and out of marriage? Perspect Sex Reprod Health. 2016;48(1):35-43. doi: 10.1363/48e8116

20. Sexton MB, Hamilton L, McGinnis EW, Rosenblum KL, Muzik M. The roles of resilience and childhood trauma history: main and moderating effects on postpartum maternal mental health and functioning. J Affect Disord. 2015;174:562-8. doi: 10.1016/j.jad.2014.

21. Matos JS, Senna AK. História oral como fonte: problemas e métodos. Historiæ [Internet]. 2011 [cited 2017 Jul 23]; 2(1):95-108. Available from: https://periodicos.furg.br/hist/article/view/2395/1286

22. Halbwachs M. A memória coletiva. 2a ed. São Paulo: Centauro, 2004.

23. Ministério da Educação (BR). Diretrizes Curriculares Nacionais Gerais da Educação Básica[Internet]. Secretária de Educação Básica (SEB). Diretoria de Currículos e Educação Integral (DICEI). Brasília: MEC, SEB, DICEl; 2013 [cited 2017 Jul 22]. Available from: http://portal.mec.gov. br/docman/julho-2013-pdf/13677-diretrizes-educacao-basica-2013-pdf/file

24. Dragan WL, Zielińska A, Zagdańska M. Childhood adversity as a moderator of the relationship between emotional reactivity and the occurrence of anxiety and depression in a non-clinical group. Psychiatr Pol. 2016;50(1):95-104. doi: http://dx.doi.org/10.12740/PP/40064

25. Child Trends Databank. Attitudes toward spanking [Internet]. Bethesda (MD); 2012 [cited 2017 Sep 30]. Available from: https://www. childtrends.org/wp-content/uploads/2015/03/indicator_1427477229.49.pdf

26. Governo do Brasil. Lei n. 8.069, de 13 de julho de 1990. Dispõe sobre o Estatuto da Criança e do Adolescente, e dá outras providências [Internet]. 9a ed. Brasília: Edições Câmara; 2012 [cited 2017 Jul 22]. Available from: http://www.crianca.mppr.mp.br/arquivos/File/publi/ camara/estatuto_crianca_adolescente_9ed.pdf

27. Florentino BRB. As possíveis consequências do abuso sexual praticado contra crianças e adolescentes. Fractal, Rev Psicol [Internet]. 2015 [cited 2017 Aug 10];27(2):139-44. Available from: http://www.scielo.br/pdf/fractal/v27n2/1984-0292-fractal-27-2-0139

28. Afifi TO, Mota N, Sareen J, MacMillan HL. The relationship between harsh physical punishment and child maltreatment in childhood and intimate partner violence in adulthood. BMC Public Health. 2017;17:493. doi: 10.1186/s12889-017-4359-8

29. Souza FBCD, Drezett J, Meirelles AC, Ramos DG. Aspectos psicológicos de mulheres que sofrem violência sexual. Reprod Clim. 2012;27(3):98-103. doi: https://doi.org/10.1016/j.recli.2013.03.002

30. McCauley HL, Blosnich JR, Dichter ME. Adverse childhood experiences and adult health outcomes among veteran and non-veteran women. J Womens Health (Larchmt.). 2015;24(9):723-729. doi: 10.1089/jwh.2014.4997

31. Baia PAD, Veloso MMX; Magalhaes CMC, Dell'aglio DD. Caracterização da revelação do abuso sexual de crianças e adolescentes: negação, retratação e fatores associados. Temas Psicol. 2013;21(1):193-202. doi: http://dx.doi.org/10.9788/TP2013.1-14

32. Nlewem C, Amodu OK. Family characteristics and structure as determinants of sexual abuse among female secondary school students in Nigeria: a brief report. J Child Sex Abus. 2017;26(4):453-64. doi: 10.1080/10538712.2017.1293202

33. Maranhão JH, Xavier AS. Sentidos do abuso sexual intrafamiliar para adolescentes do sexo feminino. Serv Soc Rev. 2014;17(1):88-112. doi: $10.5433 / 1679-4842.2014 \mathrm{v} 17 \mathrm{n} 1 \mathrm{p} 88$

34. Bérgamo LN, Bernardes MP. Relato de experiência: avaliação psicológica de uma criança vítima de abuso sexual fundamentada no psicodrama. Rev Bras Psicodrama. 2015;23(2):67-74. doi: http://dx.doi.org/10.15329/2318-0498.20150008

35. Wan Y, Liu W, Sun Y, Hao J, Tao F. Relationships between various forms of childhood abuse and suicidal behaviors among middle school students. Zhonghua Liu Xing Bing Xue Za Zhi. 2016;37(4):506-11. doi: 10.3760/cma.j.issn.0254-6450.2016.04.013

36. Veloso MMX, Magalhães CMC, Cabral IR. Identificação e notificação de violência contra crianças e adolescentes: limites e possibilidades de atuação de profissionais de saúde. Mudanças. 2017;25(1):1-8. doi: http://dx.doi.org/10.15603/2176-1019/mud.v25n1p1-8

37. Antoniassi LJ, Tapia CEV, Aquino JP. Papel do enfermeiro frente ao abuso sexual de crianças e adolescentes. Rev Saúde em Foco [Internet]. 2014 [cited 2017 Aug 10];1(1):93-102. Available from: http://www4.fsanet.com.br/revista/index.php/saudeemfoco/article/view/316

38. Ministério da Saúde (BR). Secretaria de Atenção à Saúde. Departamento de Atenção Básica. Passo a Passo PSE: Programa Saúde na Escola [Internet]. Brasília: Ministério da Saúde; 2011 [cited 2017 Aug 15]. Available from: http://189.28.128.100/dab/docs/legislacao/passo_a_ passo_pse.pdf 